This PDF is a selection from an out-of-print volume from the National Bureau of Economic Research

Volume Title: Long-Range Economic Projection

Volume Author/Editor: Conference on Research in Income and Wealth

Volume Publisher: NBER

Volume ISBN: 0-691-04141-5

Volume URL: http://www.nber.org/books/unkn54-1

Publication Date: 1954

Chapter Title: National Productivity and its Long-Term Projection

Chapter Author: John W. Kendrick

Chapter URL: http://www.nber.org/chapters/c2931

Chapter pages in book: (p. 67 - 104) 


\title{
NATIONAL PRODUCTIVITY AND ITS LONG-TERM PROJEGTION
}

\author{
JOH N. KENDRICK \\ NATIONAL BUREAU OF ECONOMIC RESEARCH
}

ThE PHysical volume of production in the economy is a function of the quantities of the factors of production utilized, and their joint efficiency or productivity. Long-term projections of gross national product basically involve projections of factor input and productivity. Because of the current limitations of our statistical information, it is more practicable to project in terms of labor, or man-hour input, and the partial productivity measure, real gross national product per man-hour, than in terms of a complete production function. This paper is concerned with the productivity sphere of the projection problem.

Successful projection of productivity involves first of all a clear concept of the variable under consideration, and the chief factors which determine its movement. Since real gross national product per unit of factor input, in aggregate and by industry, differs in important respects from most other productivity measures, considerable space will be devoted to clarifying the concept. The main factors which affect the movements of this type of productivity measure will be discussed theoretically.

As Dr. Kuznets pointed out in his introductory paper, projection involves a knowledge of persistent patterns of behavior in past periods. Accordingly, another section of this paper describes calculations of secular trends in national productivity over several past decades. Productivity trends in the farm and nonfarm sectors of the private economy are measured separately in order to illustrate the industry approach to productivity analysis.

The discussion of projections of productivity is largely related to technique. The types of adjustment which would have to be made in extrapolations of past productivity trends in order to obtain a projection articulated with the relevant details of the economic projection as a whole are developed. Finally, the areas are indicated in which further data, analysis, and theory are

Note: At the time this paper was prepared, the author was acting chief of the National Economics Division of the Department of Commerce. He bears full responsibility, however, for the views expressed herein, as well as for the supporting estimates. 
needed to advance our knowledge of productivity and thus our ability to project.

\section{A. PRODUCTIVITY CONCEPT \\ IN A GROSS NATIONAL PRODUCT FRAMEWORK, IN THE AGGREGATE AND BY INDUSTRY}

There are many distinct concepts and measures of productivity. Real product per man-hour, in the aggregate or by industrial origin, used in connection with over-all economic projections, differs in a number of important respects from other types of productivity measures. Understanding of the distinctive features of productivity measurement in a real product framework is essential to its use for analysis or projection.

\section{Real product dividend-a net output concept}

Gross national product measures the market value of the nation's economic output of final goods and services. The concept upon which the discussion in this paper is based is that of the Department of Commerce. It is clear that different concepts and measures of national product could affect the derived movement of productivity. Differing definitions of final product as opposed to intermediate product, for example, could have a significant influence on the derived productivity measures. ${ }^{1}$ On the other hand, the line drawn between economic and noneconomic activities, while affecting the movements of total national product, should not be very important in productivity measurement, since the delimitations chosen would affect both output and input.

The influences of price changes are eliminated from gross national product by dividing the current dollar expenditure estimates, in the finest possible product detail, by appropriate indexes of market prices. This procedure ideally yields the same result as weighting the physical volume of output of the various types of final goods and services by base period market prices. The problems of price deflation, and possible biases in movements of constant dollar ("real") product, are discussed else-

1 Some critics maintain that part of government purchases of goods and services as measured by the Department of Commerce represents intermediate products furnished business, and should be excluded from gross national product. See "Discussion of the New Department of Commerce Income Series," The Review of Economics and Statistics, Vol. xxx, No. 3, August 1948. 
where. ${ }^{2}$ Although any such measure has certain imperfections, it is currently the most practicable way of estimating the total physical volume of final output in the economy. For one thing, physical volume measures are not available for all industries. Most of the available industry measures are on a gross output basis, which differs from the gross national product concept.

Gross national product, in current and in constant dollars, is "gross" in that no deduction is made for business and institutional consumption of capital goods. It is "net," however, in the important sense that all other intermediate products, such as raw materials, semifinished goods, or components-other than those entering the net change in inventories-are excluded.

This factor may quite significantly affect the movement of real product relative to the volume of gross output, and the productivity measures derived therefrom. For example, economies in the use of intermediate products, given the same gross output in two periods, are reflected in an increase in real product. Input factors remaining constant in relation to outputs, an increase in productivity would result, because of both the increase in real product and the decrease in man-hour inputs, as man-hours engaged in intermediate production are reduced. Composite physical production series based on gross output would not only show no increase under these circumstances, but, if they covered the entire economy, would decline because of the smaller volume of output of intermediate products. A composite productivity series, based on gross output dividends, would show no change, abstracting from the effect of interindustry shifts.

The gross national product by individual industries of origin, while gross with respect to capital consumption, is likewise net with respect to intermediate products consumed. Estimated from the product side, gross industrial product is, broadly speaking, measured by the value of gross output (and inventory changes) less the value of intermediate products consumed in the production process. If intra-industry sales are included in the value of gross output, then an equivalent amount, representing intra-industry purchases, would be included in the deduction for value of intermediate products consumed. If, however, value of gross output is defined and measured net of intra-industry sales, then

${ }^{2}$ George Jaszi and John W. Kendrick, "Estimates of Gross National Product in Current and Constant Dollars, 1929-49," Survey of Current Business (Department of Commerce), January 1951. 


\section{NATIONAL PRODUCTIVITY}

the value of intermediate products represents purchases from other industries. In either case, the industrial product estimate is the same, and is additive to the gross national product estimates for other industries.

Gross industrial product, as a value-added type of concept, is equivalent to the sum of income accruing to the factors of production, plus indirect business taxes and capital consumption allowances. For deflation purposes, however, the product data are essential. Real industrial product is obtained as the difference between the value of gross output, adjusted for price changes by detailed product groupings, and the value of intermediate products consumed, deflated likewise.

Thus, the real product of an industry will move differently from the physical volume of gross output if the ratio of real purchases of intermediate products to the real value of gross output varies. Most productivity measures are based on gross output, and therefore do not allow for changing proportions of intermediate products consumed. Yet this factor is definitely relevant to productivity measurement.

These points are illustrated in the hypothetical model shown in Table 1 for individual industries and the economy as a whole. For the sake of simplicity, the model relates to an economy composed of two industries, $A$ and $B$.

In industry $A$, because of the increasing proportion of intermediate products consumed, the national product rises less than the value of gross output. In industry $\mathrm{B}$, the reverse is true. Because of the greater importance of industry $B$ in the economy as a whole, the over-all proportion of intermediate products consumed declines and the total national product rises more than the value of the total gross output.

These examples are hypothetical, but not necessarily unrealistic. The real gross farm product in the United States has behaved like the national product of industry A. (See Section B-2-a.) This behavior may be typical of extractive industries generally, when there is a strong tendency toward diminishing returns. The extractive industries, however, currently account for a minor proportion of gross national product.

The hypothetical data for industry B may generally typify manufacturing industries, although good data over time concerning intermediate products consumed would be required for verification. Certainly scientific industrial controls, which have 


\section{NATIONAL PRODUCTIVITY}

TABLE I

The National Product of a Hypothetical Economy (IN MONETARY UNITS OF CONSTANT VALUE)

\begin{tabular}{lrrr}
\hline & \multicolumn{2}{c}{ TIME PERIODS } & PERCENT \\
& $I$ & $I I$ & CHANGE \\
\hline Industry A & & & \\
Value of gross output & 100 & 100 & \\
$\quad$ Final products & 50 & 100 & \\
$\quad$ Intermediate products & 150 & 200 & +33 \\
$\quad$ Total & 50 & 80 & +60 \\
Value of intermediate products consumed & 100 & 120 & +20 \\
National product of Industry A & & & \\
Industry B & & & \\
Value of gross output & 200 & 620 & \\
$\quad$ Final products & 50 & 80 & \\
Intermediate products & 250 & 700 & +180 \\
$\quad$ Total & 50 & 100 & +100 \\
Value of intermediate products consumed & 200 & 600 & +200 \\
National product of Industry B & & & \\
Total economy & 400 & 900 & +125 \\
Value of gross output & 100 & 180 & +80 \\
Value of intermediate products consumed & 300 & 720 & +140 \\
Total national product & & &
\end{tabular}

helped to economize the utilization of raw materials, and the increasing degree of processing have tended to reduce the proportion of intermediate products consumed. ${ }^{3}$ This tendency may prevail in the economy as a whole. The net-versus-gross comparison for any individual minor industry would depend on the industrial classification scheme followed. The scheme would have to be consistent for the period studied if the tendency toward increasing specialization were not to be reflected as an increase in the intermediate product ratio for any one industry.

In any case, it is apparent that gross output data may be misleading in an economic sense. Consumption of intermediate

${ }^{3}$ Mr. V. R. Berlinguette, of the Dominion Bureau of Statistics of Canada, in a paper presented to the September 1950 meeting of the Econometric Society, "Limitations on Measurement of Physical Production," reviewed the few scattered attempts to measure the volume of net industrial output, and presented statistics relating to Canadian industry. On the basis of a study of 21 industries representing close to 25 percent of the total net value of manufacturing production for the period 1935-47, he concluded: "On balance, the index based on net output was significantly higher than that based on gross production, indicating that the degree of processing per unit of output had increased over the period covered." See summary of paper in Econometrica, Vol. 19, No. 1, January 1951, pp. 71-72. 


\section{NATIONAL PRODUCTIVITY}

products represents an important real cost of production, and for most purposes of economic analysis allowance should be made for changes in this variable relative to changes in gross output. This is especially true as regards productivity measurement, since efficiency in the use of materials is usually a relevant aspect of the problem. It is this writer's opinion that allowance for changing ratios of intermediate products consumed is better made in the dividend of the productivity equation, reserving the divisor for use as a measure of factor input.

Capital consumption allowances have also varied as a percentage of gross national product. If it were possible to make meaningful estimates of real capital consumption allowances, it would undoubtedly be desirable to measure productivity in terms of "net national product" in constant dollars.

\section{The factor input divisor-the real cost of productive services}

The physical volume of production is a function of the quantity and quality (or "efficiency") of the factors of production employed. The basic factors are customarily defined as: land, in the broad sense of natural resources; capital-plant and equipment, and working stocks; and the human labor force. These factors form stocks, or social and economic capital, while the employment or input in production of the factors represents flows of productive services, or "real costs."

The physical volume of input of the factors must be defined and measured carefully to avoid counting changes in efficiency as changes in physical volume. If changes in efficiency of each of the factors could be measured separately, and were counted as changes in the volume of input, then there would be no change in productivity, since the changes in output relative to input would have been imputed to the various input factors.

For each factor, the physical unit input or real cost can be measured as the physical volume of the stock in productive employment times the base period rate of remuneration or cost of the flow of factor services. The total of this constant-dollar flow of services from all factors would provide a measure of the composite physical volume of factor input.

It would seem logical to measure real factor costs for each industry separately. If relative prices or costs of factors, as well as of final products, in the base period, are accepted as a yardstick of relative physical volumes, then shifts of factors to indus- 


\section{NATIONAL PRODUCTIVITY}

tries with higher than average unit cost should be reflected as increases in the volume of input.

Most productivity measurements have related output to labor input only in terms of man-hours. This has been partly due to expediency, and partly due to the greater interest attaching to production in terms of persons or man-hours employed, possibly because of the close relationship of this concept to the ideas of real income and standards of living. However, it is clear that the real volume of input of the other factors relative to labor input influences the movement of the productivity quotient, as well as the efficiency of all the factors.

To make more explicit the assumptions involved in using a man-hour productivity measure, Table 2 has been set up, carrying the data of Table 1 a step further to show the relation of the input measures to each other, and to the real gross products in the component industries and in the hypothetical economy as a whole. The figures in parentheses are the series by which the

\section{TABLE 2}

Real Factor Input, by Type, Relative to Real Product IN a HYPOTHeTical ECONOMY

(IN MONETARY UNITS OF CONSTANT VALUE, AND MAN-HOURS )

\begin{tabular}{lccc}
\hline & \multicolumn{2}{c}{ TIME PERIODS } & PERCENT \\
& $I$ & $I I$ & CHANGE \\
\hline Industry $A$ & & & \\
National product & 100 & 120 & +20 \\
Factor cost & 100 & 106 & +6 \\
$\quad$ Labor cost & 70 & 70 & 0 \\
$\quad$ (Man-hours worked) & $(100)$ & $100)$ & \\
Property cost & 30 & 36 & +20 \\
$\quad$ (Real value utilized) & $(500)$ & $600)$ & \\
Industry B & & & \\
National product & 200 & 600 & +200 \\
Factor cost & 200 & 480 & +140 \\
Labor cost & 120 & 240 & +100 \\
$\quad$ (Man-hours worked) & $(100)$ & $(200)$ & \\
Property cost & 80 & 240 & +200 \\
$\quad$ (Real value utilized) & $(1,000)$ & $(3,000)$ & \\
Total economy & & & \\
National product & 300 & 720 & +140 \\
Factor cost & 300 & 586 & +95 \\
Labor cost & 190 & 310 & +63 \\
$\quad$ (Man-hours worked) & $(200)$ & $(300)$ & +50 \\
Property cost & 110 & 276 & +151 \\
$\quad$ (Real value utilized) & $(1,500)$ & $(3,600)$ & +140 \\
\hline
\end{tabular}


base period factor costs were moved-except for the total, in which case they are the unweighted sum of the data by industries. For the sake of simplicity, the returns to land and capital have been lumped as "property cost."

Before discussing the relationship of the various measures of factor input, a few words should be said concerning the conceptual and statistical problems involved in measuring actual total real factor input in the United States economy.

In the first place, to obtain an equivalence between factor cost and national product in the base period, real product would have to be revalued in terms of factor prices, which would mean deducting indirect business taxes and capital consumption allowances from the Commerce data, and adjusting the data for subsidies and statistical discrepancy. ${ }^{4}$

Labor cost in the base period should be inclusive. That is, the labor compensation element in entrepreneurial income should be segregated and included with the wages, salaries, and supplements of all types of employees.

Base period labor cost (by industry) would be moved by man-hour data. Although some productivity measures relate to average employment only, average hours worked measures the rate of utilization of employed workers, and is a closer approximation to labor input.

All types of labor should be included in the man-hour dataand are, in the data presented later: entrepreneurs (business and professional) and family workers; management and other administrative workers; and production workers, direct and indirect. Productivity measures related only to certain types of labor are influenced by the movement of the ratio of uncovered labor to the type of labor included in the divisor.

The property cost shown in the table includes the rents and royalties of land, and the return on capital. There would be difficult problems involved in obtaining a segregation in the base period. Some capital is leased, so that data on "rents" include part of the return on capital as well as the rents of land. On the other hand, the data on corporate profits and entrepreneurial income include rent (imputed) on land owned by the business. The income accruing to capital would include net interest and the

4 This procedure raises difficult, statistical problems, especially when carried through on an industry basis. The general discussion in this paper of real product at factor prices, and of total real factor cost, is purely theoretical. 


\section{NATIONAL PRODUCTIVITY}

profit element of entrepreneurial income and corporate profits after inventory and depreciation valuation adjustments.

The real input of land would be computed as the base period ratios of net rent to the total value of land employed in the various industries moved by the quantities of land, the latter possibly adjusted by a use-intensity ratio.

The real cost of capital could be computed as the base period return on the net value of capital (buildings, equipment, and inventories) moved by the constant-dollar net value of capital employed, times a factor representing the degree of capacity utilization. Needless to say, estimating the constant-dollar value of capital assets and depreciation valuation adjustments would present difficult statistical problems. ${ }^{5}$

In the example, total man-hours show a smaller increase than real labor cost. This would always be true when there is a relative shift of labor toward higher-pay industries. Man-hours are interchangeable with real labor cost only on the assumption that there has been no shift in the industrial composition of man-hours employed.

Total real factor cost shows a greater increase than labor cost. This would be so whenever the ratio of the total real value of property per man-hour is increasing, which has probably been true generally of progressive economies. Thus, aggregate productivity would show a smaller secular rate of increase than labor productivity alone.

In my opinion, it will be salutary when productivity measurement and projection can be done in terms of total factor input, so that explicit account may be taken of property input. When only labor productivity is used, projections should be made at least with awareness of the property factor. Projections of past rates of increase imply not only that technical advance will keep up with past trends, but also that the relationship of real property input to labor input will continue according to past patterns. If this assumption is not consistent with other aspects of the economic projection, the productivity projection should be modified accordingly.

\section{Productivity quotient-joint efficiency of the factors of production}

"Productivity" is not an independently observable variable, but

SSee Raymond W. Goldsmith, "A Perpetual Inventory of National Wealth," Studies in Income and Wealth, Volume Fourteen (NBER, 1951). 
is a meaningful abstraction. Mathematically, it is the quotient of output and factor input, however defined. The precision with which it can be measured depends on the quality of the underlying data. Economically, the content or meaning of productivity change depends on the definition of the concept.

Defined as real product per unit of factor input (whether total real factor cost, real labor cost, or man-hours), composite productivity changes reflect changes in the joint efficiency of the factors, because of both technical and economic forces-as well as the influence of the real volume of input of uncovered factors if only part of factor input is used.

Changes in output of specific types of goods and services relative to factor input reflect technical forces. Productivity advances in this sense stem from increases in knowledge concerning production, and their application to productive procedures and instruments through technology. This type of "pure" productivity measure for broad segments of the economy is usually approximated by combining productivity series by a system of constant weights.

Aggregate real product per unit of factor input is also influenced by the effect of variable input weights applied (implicitly) to productivity movements of individual industries. This influence may be termed economic, since it stems from shifts in relative demand. By taking separate account of this influence, productivity analysis and projection can be more precise.

\section{a. ECONOMIC EFFICIENCY}

Real product per unit of factor input changes not only as productivity in the component industries change, but also as the weights used to combine the real products per unit of factor input in the various industries change.

These weights are, implicitly, the relative real factor costs in the various industries in any given year. This factor is economic, since it depends on the relative demand for the productive factors by industry, which, in turn, is a result of the relative demand for final goods and services. Final demand shifts as tastes change, and in response to changes in relative prices which reflect changes in relative costs. In a sense, relative changes in productivity itself are a partial cause of the industrial composition of factor input, 


\section{NATIONAL PRODUCTIVITY}

since they influence the relative costs of the factors in the various industries.

In the case of real product per unit of aggregate factor input, a shifting composition of aggregate factor input by industry affects the movement of productivity only insofar as productivity movements by industry differ. If, on net balance, factor input shifts toward industries whose productivity rises more rapidly than the average, the rise in aggregate productivity will be greater than that indicated by application of base period weights to the component industrial productivity series.

In the case of real product per unit of labor input (real cost or man-hours), aggregate productivity is affected not only by differential productivity movement by industry, but also by the different levels of real product per unit of labor input in the various industries. If, on net balance, labor input shifts toward industries with higher levels of real product per unit of labor input than the average, total real product per unit of labor input will rise, apart from any changes in labor productivity in the various industries. This effect will be reinforced, of course, if the industries with higher than average real product per unit of labor input are also those in which productivity is rising more rapidly than the average.

From an aggregate economic viewpoint, the influence of the shift of resources among industries should be reflected as productivity changes. A shift of resources toward industries in which the real product per unit of factor cost is higher than average represents a real gain to the community, since the utility in terms of base period relative values, created by the factors in their new employment, is greater than in the old. Thus the factors are more "efficient" in an economic sense.

The effects of variable factor cost weights may be seen in Table 3, which spells out the productivity implications of Table 2.

It was seen in Table 2 that industry $B$ has a higher value added per unit of labor input than industry $A$ and also shows a greater increase in productivity. The higher real product results from a higher ratio of real property to labor and higher rates of return to both property and labor.

However, in the case of real product per unit of total factor input, since productivity in both industries is unity in the base period, aggregate productivity is influenced only by the shift of input toward the more rapidly rising productivity series. 


\section{NATIONAL PRODUCTIVITY}

In the case of labor productivity, the shift of labor toward the industry with the higher level of productivity also influences the aggregate productivity. Since the differential in levels of productivity is greater in the case of man-hour productivity than for productivity based on real labor cost, the shift of relative manhours between industries causes a greater increase in aggregate

TABLE 3

Productivity Measures in a Hypothetical Economy Using Different InPUt Measures and Different Weighting Systems (IN MONETARY UNITS OF CONSTANT VALUE)

\begin{tabular}{|c|c|c|c|}
\hline & TIN & AIODS & PERCENT \\
\hline & $I$ & II & CHANGE \\
\hline Industry $A$ & & & \\
\hline National product pe & & & \\
\hline Total factor cost & 1.00 & 1.13 & +13 \\
\hline Labor cost & 1.43 & 1.71 & +20 \\
\hline Man-hours & 1.00 & 1.20 & +20 \\
\hline Industry $B$ & & & \\
\hline National product pe & & & \\
\hline Total factor cost & 1.00 & 1.25 & +25 \\
\hline Labor cost & 1.67 & 2.50 & +50 \\
\hline Man-hours & 2.00 & 3.00 & +50 \\
\hline Total economy (varial & & & \\
\hline National product pe & & & \\
\hline Total factor cost & 1.00 & 1.23 & +23 \\
\hline Labor cost & 1.58 & 2.32 & +47 \\
\hline Man-hours & 1.50 & 2.40 & +60 \\
\hline Total economy (const & & & \\
\hline National product pe & & & \\
\hline Total factor cost & 1.00 & 1.21 & +21 \\
\hline Labor cost & 1.58 & 2.21 & +40 \\
\hline Man-hours & 1.50 & 2,10 & +40 \\
\hline Effect on aggregate $p$ & & & \\
\hline $\begin{array}{l}\text { variable input weights } \\
\text { National product pe }\end{array}$ & & & \\
\hline Total factor cost & & & +2 \\
\hline Labor cost & & & +5 \\
\hline Man-hours & & & +14 \\
\hline
\end{tabular}

productivity on a man-hour basis than the shift in real labor cost causes on that basis.

It should not be thought that the increases in productivity on a man-hour basis are any less real because they show a larger influence of the shifting distribution of man-hours among industries. The meaning and movement of any productivity measure is relative to its definition. Man-hour productivity is certainly a 


\section{NATIONAL PRODUCTIVITY}

legitimate concept, and can be used as a projection tool. It is merely based on an incomplete measure of factor input, and one that probably rises less rapidly than total real factor cost. These characteristics should be consciously considered in using the measure.

\section{b. TECHNICAL EFFICIENCY}

Most conventional composite productivity measures attempt to isolate changes in technical efficiency by using constant weights to combine individual industrial productivity index numbers. Insofar as the relative weights are of the value-added type, corresponding to the relative gross products originating in the various industries, these composite index numbers correspond to the productivity measures using constant weights based on relative factor input shown in Table 3.

The economic factor is not entirely eliminated from such constant weighted indexes, however, since intra-industry shifts of the factors among products with differing productivity levels and/or changes affect the movement of productivity in the individual industry. "Pure" productivity change based on technical factors alone could be measured only in terms of individual products. But it is true that a composite productivity index for the economy as a whole, using constant weights for the component industrial productivity series, comes closer to the concept of pure technical productivity than one using variable weights.

The causes of the changes in productivity from the technical angle lie in the fundamental activities which result in changes in efficiency, or output capacity of a given quantity of the factors in combination.

It is impossible to segregate the changes in efficiency attributable to any one factor, although, obviously, changes in joint productivity can be related to, or measured in terms of, any one factor. This is because changes in efficiency of one factor usually require and are accompanied by a progressive adaptation of the other factors to the changed shape of the services rendered by the factor initiating the change in production technology. For example, new machinery requires retraining of workers and possibly a reorganization of plant layout, work flows, and the like.

The fundamental activities producing improved efficiency of the factors relate to improvements in technology and to the rate of incorporation of technical innovations into the body of factors 


\section{NATIONAL PRODUCTIVITY}

employed. Technological innovations rest on advances in human knowledge, which in systematized form may be called scientific progress. Advances in knowledge result from research, whether formalized as a distinct function or not. These advances are frequently directed toward, or may be adapted to, improvements in concrete procedures or instruments of production, resulting in technical innovations, or "inventions."

Research and development work is directed not only toward improving productive plant and equipment. It is also devoted to raising the level of physical and mental health, and the efficiency of human beings in their productive activity and in the rest of their lives, which also bear importantly on work efficiency. Much of the investment in personal efficiency is made by individuals themselves, as, for example, with education.

Research and development activity is also devoted to the problems of land and resource use to increase the productivity of land with a given input of the other factors. It is also devoted to problems of the use, improvement, and substitution of materials, which, as we have seen, affect real product per unit of factor input through the dividend of the equation.

A measure of real research and development outlays, with a distributed time lag, should show a high degree of correlation with changes in technical productivity. No attempt is made here to tackle the difficult problem of precise definition and measurement of the volume of research and development activity. However, as such activity increasingly becomes a distinct, organized function in business firms, the possibility of such measurement becomes greater.

Indeed, this type of intangible work, which represents current expenditures devoted (directly or indirectly) to the object of increasing productive efficiency in the future, might well be classified as "investment" in the national accounts, instead of being charged to current expense, as is done in the case of the business economy.

If such a procedure were eventually adopted, the gross business product would be higher by the amount of expenditures for research and development. On the income side, profits would be higher by a like amount. Government and personal purchases falling in the "intangible investment" category could also be segregated, but since these expenditures are already counted as final product, no adjustment of the totals would be required. 


\section{NATIONAL PRODUCTIVITY}

The rate of adoption of new developments and adaptation of productive organization to technical change also affects productivity. This is hard to measure in respect to personnel procedures, plant layout, organization of work flows, and the like. It is a more tangible factor in the case of plant and equipment, where the average age of the capital furnishes an index of the rate of incorporation of new devices into the body of productive capital. Likewise, changes in the average education, training, and health per worker are susceptible to rough measurement. The spread of improved methods of land management and resource use is likewise relevant, but probably difficult to measure.

Even this brief review of some of the dynamic factors which cause changes in productivity shows the difficulty of devising a quantitative measure of these forces. What can be done is to relate productivity measures to time, and (after abstracting from the effect of changing weights) to consider the average annual rate of increase in productivity as the net effect and measure of the combined influence of the various dynamic forces behind factor efficiency.

Projection of a past rate of growth in productivity is based on the implicit assumption that intangible investment per unit of factor input and the rate of incorporation of new technique into productive capacity will proceed at past rates.

\section{B. PAST TRENDS IN NATIONAL PRODUCTIVITY}

Long-term projection is basically a matter of extrapolating past trends modified by introducing the effects of anticipated or assumed abnormal changes in relevant factors. This section describes the calculation of past productivity movements and trends in the private economy. A brief description of the underlying estimates follows in Table 4.

The estimates of gross private product in constant (1939) dollars from 1929 forward are those published by the Department of Commerce. ${ }^{6}$ The gross government product, which is equivalent to compensation of general government employees according to the Commerce concept, was excluded from the total. This was done because in the constant dollar series this item, by major categories, was moved by employment or man-

'See 1951 "National Income Supplement" to the Survey of Current Business (Department of Commerce), Part rv. 


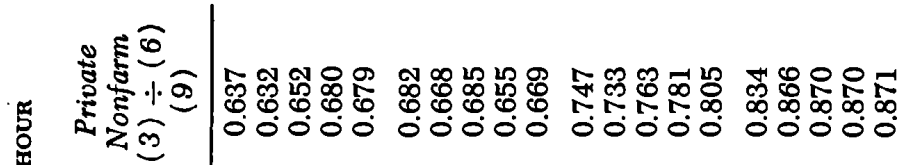

范

을

$\sqrt{20}$

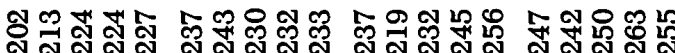

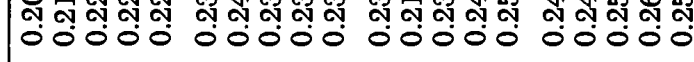

以ี

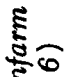

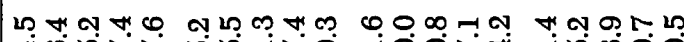

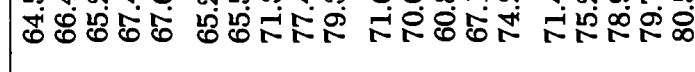

ง

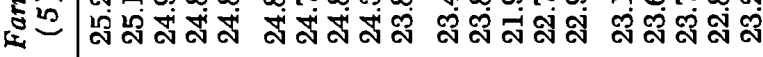

ป气

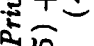

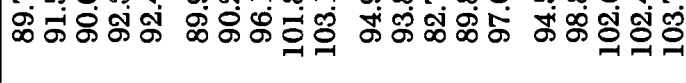

เล

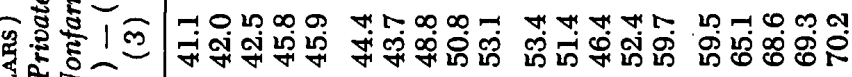

Eิ 
NATIONAL PRODUCTIVITY

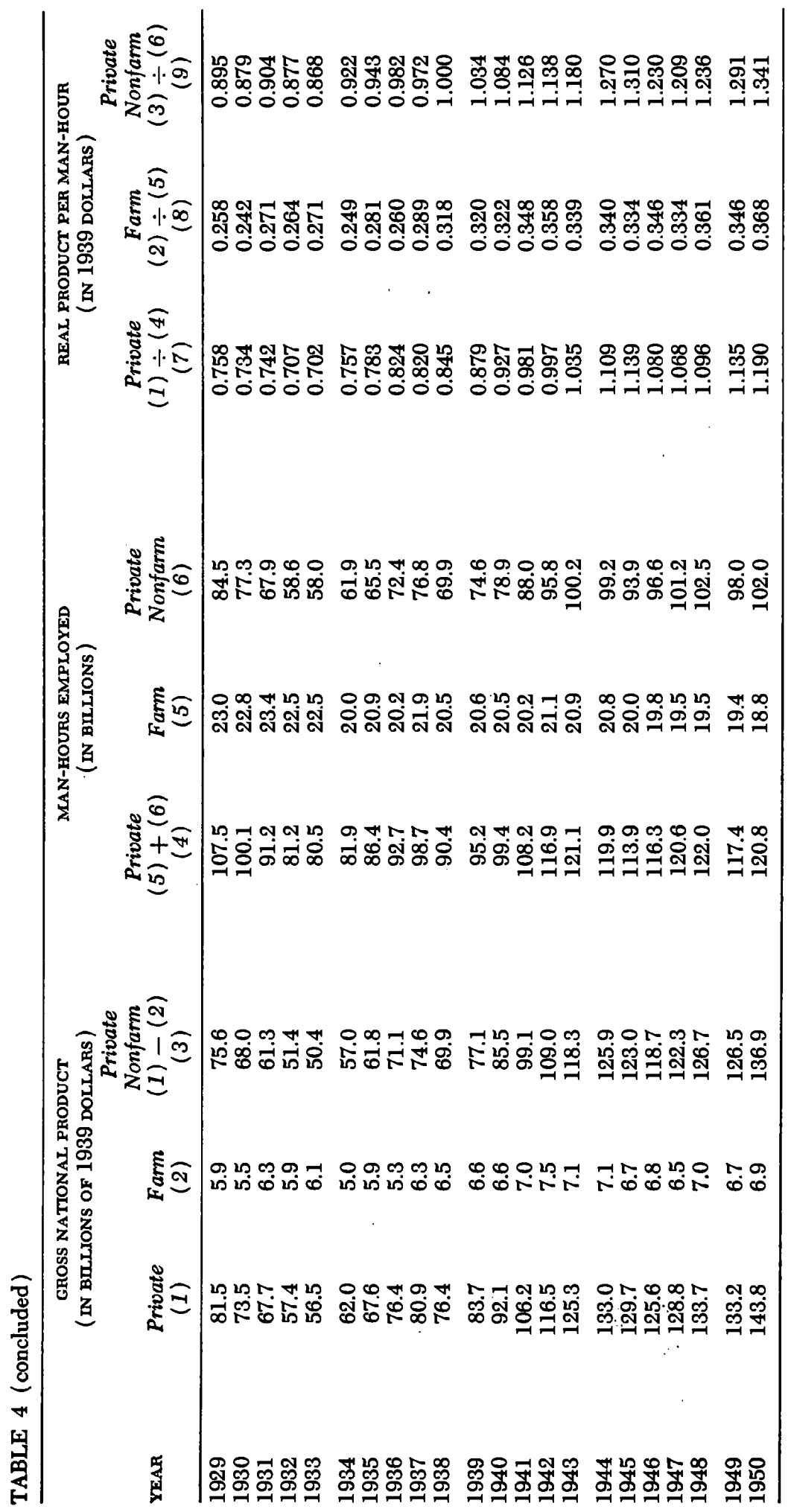




\section{NATIONAL PRODUCTIVITY}

hours, because of the lack of objective means for measuring output and productivity in large areas of government activity. Thus, the productivity estimates are based on the real product originating in the private economy, including purchases by government from the private sector, but excluding product originating in government.

The Commerce Department gross national product estimates and price deflators were extrapolated by detailed components from 1929 back to 1909 by the author, using sources described in the Appendix. Although the estimates for the earlier period were made as carefully as a few months' time permitted, they are subject to a considerable margin of error and should be superseded by more authoritative series on the Commerce concept which may appear. The estimates of real gross farm product are those published by the Department of Commerce. ${ }^{7}$

The private nonfarm employment estimates from 1929 to 1950 are based on Department of Commerce estimates and include proprietors as well as full- and part-time employees. Numbers of unpaid nonfarm family workers were added. This series, by industries, was extrapolated back from 1929 to 1919 by Bureau of Labor Statistics estimates and from 1919 to 1909 by National Industrial Conference Board data. ${ }^{8}$ The employment estimates, by major industries, were multiplied by estimates of average hours worked per week (derived from various sources, mainly the Bureau of Labor Statistics), and raised to an annual level. Average hours worked by industries and by types of labor for which data are unavailable (especially in the earlier periods) were assumed to move as the average for the covered industries and types. Man-hours worked on farms are Bureau of Agricultural Economics estimates for 1917-50 extrapolated back by an employment series from the same source. It should be noted that the BAE estimates are based on a somewhat different concept and methodology from those used in the nonfarm estimates. ${ }^{\circ}$

More intensive reworking of past data is needed, especially

"See "Gross National Farm Product in Constant Dollars, 1910-50," by John W. Kendrick and Carl E. Jones, in Survey of Current Business (Department of Commerce), September 1951.

8 Monthly Labor Review (Bureau of Labor Statistics), October 1949; and The Economic Almanac (National Industrial Conference Board) for 194647.

- See Department of Agriculture Technical Bulletin No. 1020, December 1950, "Gains in Productivity of Farm Labor," by Reuben W. Hecht and Glen T. Barton. 


\section{NATIONAL PRODUCTIVITY}

for the period prior to 1929 . The productivity trend calculations presented below, while probably of the right general order of magnitude, are subject to revision when better underlying estimates become available.

\section{Productivity trends in the private economy as a whole}

Chart 1 shows the net regression on time of productivity in the private economy, fitted to data for the years 1909-41. A second independent variable, the ratio of civilian employment to civilian labor force, was employed in the equation and held constant at 96.5 percent in the calculation of the "net trend." Because of the

\section{CHART 1}

Real Gross Private Product per Man-Hour, 1909-50

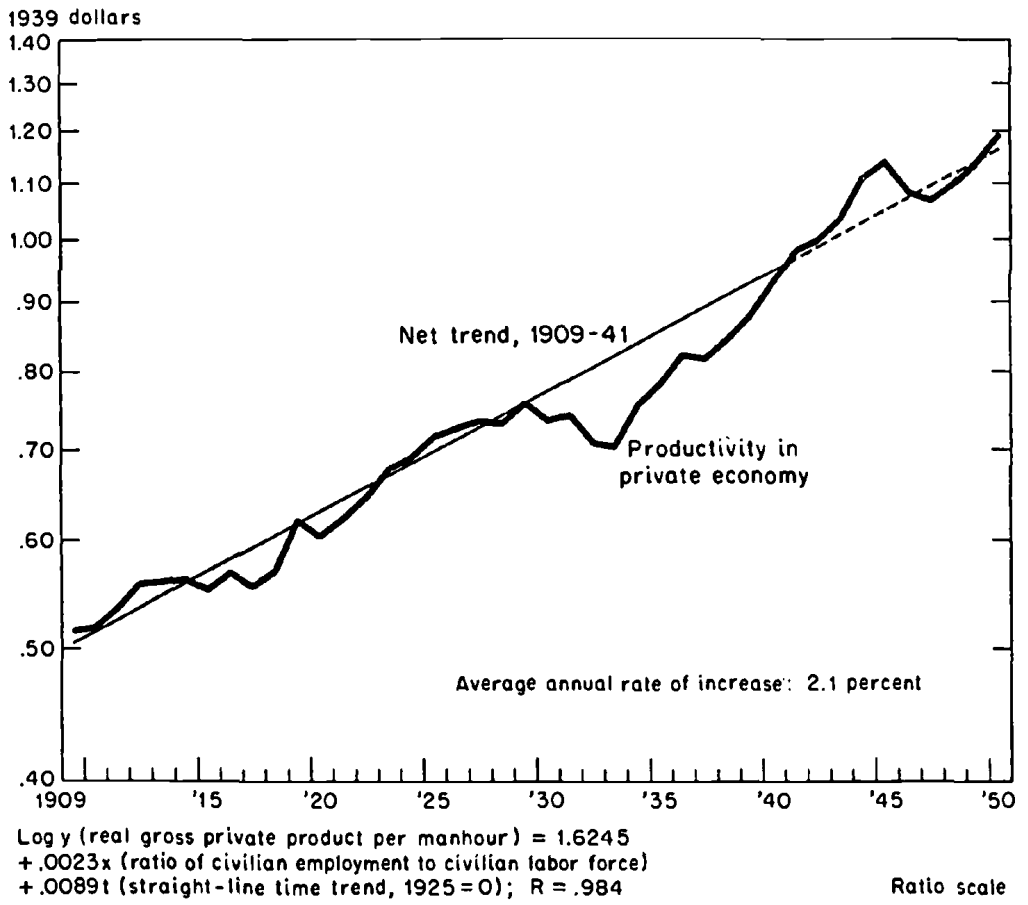

various violent disturbances associated with depression, war, and postwar readjustment, which have affected the American economy from 1929 to date, it did not appear wise to fit a simple trend line to the entire period.

The war and postwar periods involved forces which affected 


\section{NATIONAL PRODUCTIVITY}

estimated productivity to such an extent that the period since 1941 was omitted altogether. The lack of comparability of munitions with nonmunitions, rationing, quality deterioration, and other disturbances render the meaning of real product during World War II dubious. Even if a conservative relative valuation for munitions is used, real private product per man-hour in the later war years swings well above the computed net trend line.

In the early postwar years, on the other hand, productivity falls well below the trend. Apart from continuation of some of the wartime disturbances, this is to be expected in the light of restrictions on new gross private domestic investment in peacetime industries during the war. Such investment restrictions resulted in a postwar capacity which was older than the prewar average, and the industrial distribution of which was imbalanced in relation to postwar demand. It was to be expected that heavy postwar expenditures for new plant and equipment would gradually raise productivity to the prewar trend line, and by 1950 this appears to have taken place.

As the 1940's fade into history, the $1942-49$ period could probably be included in productivity trend calculations without distorting the results appreciably. But coming at the end of the historical period now under consideration, it was felt that the long-term trend would be distorted to some extent by inclusion of these years.

The problem of the 1930's is a different one. By 1933, productivity had fallen well below the trend line, and whereas the discrepancy was subsequently made up gradually, it was not until 1941 that productivity was almost back in line with the historical trend.

The depression period must have been associated with inefficiently low rates of utilization of capacity and low levels of new investment, with consequent aging of the stock of capital per worker, to mention the most important characteristics. The introduction of a variable describing the cyclical factor was indicated if use was to be made of the 1929-41 data in calculating the trend. For this variable, the ratio of civilian employment to the civilian labor force was used, based on Census Bureau and BLS estimates. The employment ratio not only takes account of fluctuations in the rate of capacity utilization, but approximates the cyclical factor generally as it affects the movement of various causative factors bearing on productivity. 
When the employment ratio is held constant, the average annual rate of growth of real private gross product per man-hour implied by the regression equation is 2.1 percent. The net trend line shown in Chart 1 is computed on the basis of holding the employment ratio constant at 96.5 percent, taken to approximate a full-employment level.

Other types of curves would, of course, yield somewhat different results. It does appear that a constant rate of growth is implied by the data for the period covered. Possibly data for earlier decades would give a different impression. Real product comparisons become increasingly tenuous, however, the longer the period included, especially when there are radical shifts in product composition.

It is interesting to note that the trend line has almost exactly the same slope as is obtained by using the period 1909-29 only, and without a third variable. The average annual growth implied is also almost the same as is computed from the real private product data for 1929, 1941, and 1950, all years of relatively high employment, and relatively free from unusual economic disturbances.

If, however, the coefficients for the same variables employed in the formula are computed for the period 1929-41 only, the implied average annual rate of productivity growth is somewhat higher-almost 2.2 percent. The longer-term picture is probably a better guide to the future, however, despite the poorer quality of the data in the early years.

\section{Productivity trends in sectors of the private economy}

It was pointed out in Part A that real gross private product per man-hour in the private economy is a composite of real gross product per man-hour in the various private industries, combined by variable man-hour weights. For projection purposes, insofar as productivity trends by industry differ and the percentage distribution by industry of man-hours worked changes, it is desirable to handle various industries separately.

Practically no work has been done to develop historical productivity estimates by industry on a real gross product basis. This is partly because of insufficiency of data. Data being developed for interindustry relationship tabulations hold promise for the future, however.

Relatively complete data for the period since 1909 already 
exist for the farm economy. This makes possible computations of real product and productivity in the private nonfarm sector. Presentation of these two sectors of the private economy separately will serve to illustrate the methodology involved in analyzing real product per man-hour by industry, and the effects on aggregate productivity of interindustry shifts of labor input.

\section{a. PRODUCTIVITY TRENDS IN THE FARM ECONOMY}

Farm productivity has been computed by a number of agencies. Generally, these computations are based on one variant or another of the physical volume of gross farm output. Such productivity computations, based on gross output, show a larger average annual rate of increase than the real gross farm product per man-hour series, shown in Table 4. This is because in real gross farm product estimates, the real value of intermediate products consumed is subtracted from the real value of gross farm output. Gross farm product is "gross" only in the sense that it includes depreciation charges; otherwise, it is "net" in that it excludes purchases of intermediate products consumed in the production process.

The ratio of the real value of intermediate products consumed to the real value of gross farm output has increased significantly. during the period 1909 to 1941 , so real gross farm product has increased substantially less over the period than the various measures of the physical volume of gross farm output.

It should be noted that the real value of gross farm output used here differs somewhat in concept, and in movement, from the several physical volume series used in other farm productivity series. The series used in the real gross farm product estimates follows the Commerce concept, which includes in the value of gross output the following items: cash receipts from farm marketings and Commodity Credit Corporation loans, the value of farm products consumed on farms where they were produced, the value of the net change in all farm inventories, and the gross rental value of farm homes.

But the most important factor distinguishing these estimates from the conventional ones remains the increasing ratio of the real value of intermediate products consumed to the real value of gross farm output. The relevant figures are shown for selected years in the following table: 


$\begin{array}{lccc} & \text { Billions of } 1939 \text { dollars } & \text { Percent } \\ & 1910 & 1941 & \text { change } \\ \text { Value of gross farm output } & 7.08 & 10.69 & +51 \\ \text { Value of intermediate products consumed } & 1.75 & 3.73 & +113 \\ \text { Gross farm product } & 5.33 & 6.96 & +31\end{array}$

Thus, the real gross farm product increased 31 percent from 1910 to 1941 , as contrasted with a 51 percent increase in the real value of gross farm output. This was because of the much greater relative increase in the real value of intermediate products consumed than in the real value of gross farm output, reflected in an increase in the ratio of the former to the latter from 25 to 35 percent over the period covered. By 1950, the ratio approached 45 percent, as real expenditures for operation of vehicles and machinery, for fertilizers, and so forth continued to climb more rapidly than the volume of production.

These comparisons would be more clearly in line with the concepts outlined in Part A if the value of gross farm output were net of sales to other farmers, and the intermediate products represented exclusively purchases from other industries. The inclusion of intra-industry sales (or purchases) in both places does not affect the gross product figure, and the movement of the "intermediate product" ratio should closely approximate the movement of a "purchases from other industries" ratio.

Most calculations of farm productivity have been on a "per worker" basis, because of the paucity of reliable average-hoursworked data for agriculture. However, in order to tie in with man-hour productivity data in the private nonfarm sector, and obtain man-hour productivity data for the private economy as a whole, a Bureau of Agricultural Economics series on man-hours worked in agriculture was used with a small adjustment for the early years. This series was derived from intensive man-hour requirement studies for various time periods. When divided by farm employment data, the man-hour series implied only a small secular decline in average hours worked over the period, much less than is apparent in the private nonfarm sector. Thus, manhour productivity computed using this series would not differ much from a per worker productivity calculation.

The man-hour productivity series obtained by dividing the real gross farm product by the man-hours data is shown on Chart 2. The employment ratio is not relevant to this computation, but it was used in order to make possible an exact reconcilia- 


\section{NATIONAL PRODUCTIVITY}

tion of the farm and nonfarm productivity trends with the trend in the private economy as a whole.

The net regression on time indicates an average annual increase of 1.2 percent in farm productivity. The coefficient of multiple correlation is not as high as for the regression equation

\section{CHART 2}

Reol Gross Form Product per Mon-Hour, 1909-50

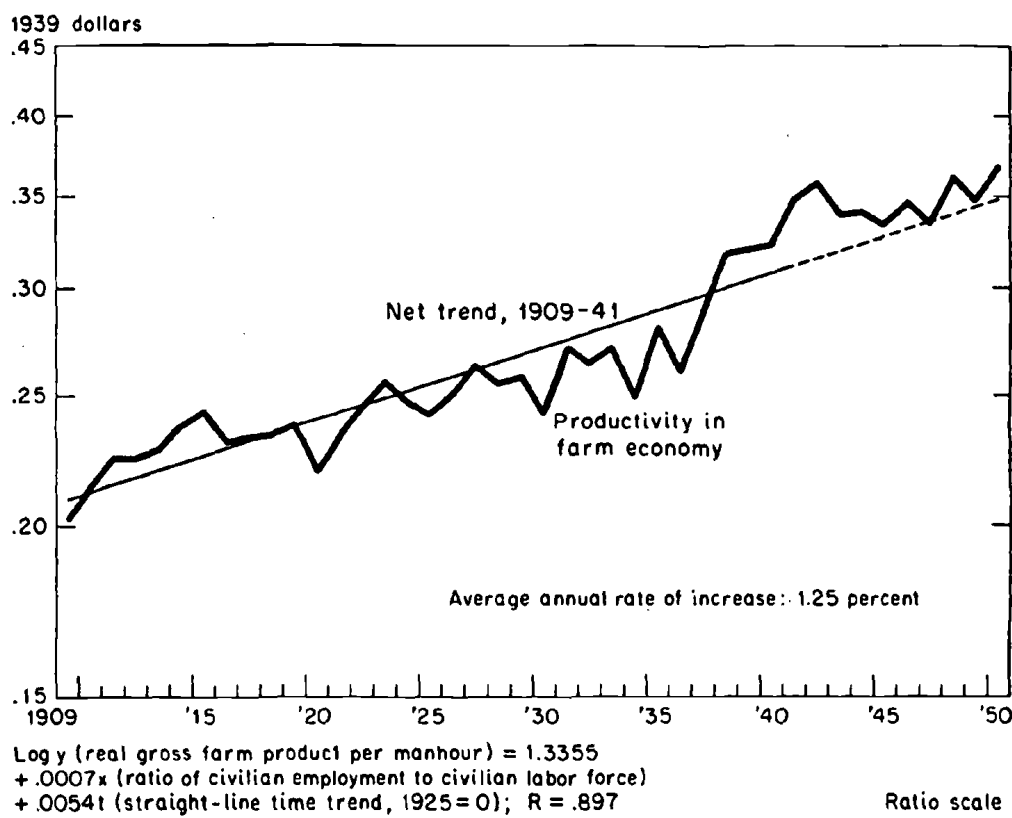

fitted to private nonfarm productivity, because of the greater importance of external influences in farming.

It will be noticed that most of the years in the 1940's are somewhat above the trend line. This may be partly because of unusually favorable weather conditions, but to some extent may represent real gains in productivity over and above the trend. The deviations above the trend in the 1940's are not as great, however, as in the productivity series based on gross output, since gross production gains were partly attributable to higher relative purchases from other industries, which are not reflected in this productivity computation. 


\section{NATIONAL PRODUCTIVITY}

\section{b. PRODUCTIVITY TRENDS IN THE PRIVATE NONFARM ECONOMY}

The real gross private nonfarm product shown in Table 4 is obtained by subtracting the real gross farm product from the total real gross private product. When divided by man-hours worked in the private nonfarm economy, the productivity series shown in Chart 3 emerges.

CHART 3

Real Gross Private Nonform Product per Man-Hour, 1909-50

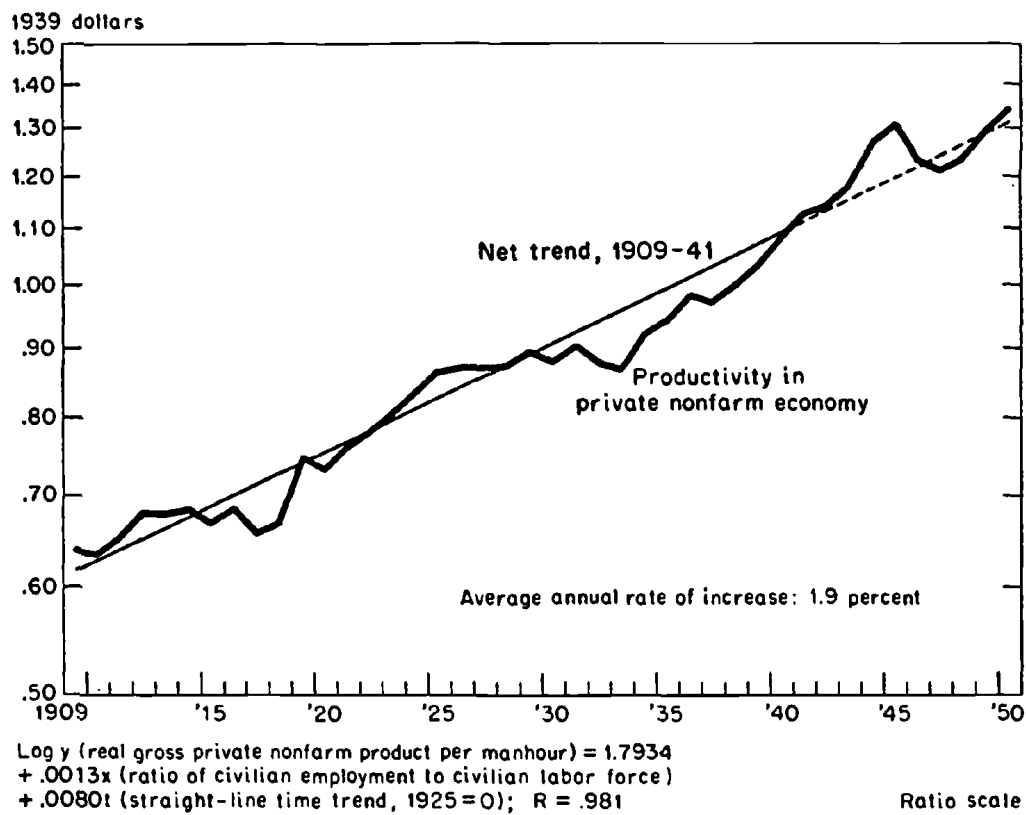

As would be expected, the movements of real private nonfarm product per man-hour are similar to those of the productivity series for the private economy as a whole-since real farm product comprised less than 10 percent of the total real private product in the period as a whole.

The same variables employed in the private productivity equation were used to describe private nonfarm productivity over the same time period, 1909-41. Holding the employment ratio constant at 96.5 percent, the average annual rate of increase of the net regression on time is 1.9 percent. The difference between this growth factor and that for the private economy as a 


\section{NATIONAL PRODUCTIVITY}

whole is due to the influence of farm productivity-its rate of growth, a downward influence, and its level, an upward influence, because of the shift of labor from the farm to the nonfarm economies, which will be discussed in the next section.

It would be desirable if real product per man-hour could be computed for individual nonfarm industries. But the real product estimates necessary for such computations do not exist. The data being developed in studies of interindustry relationships give promise for the future. This approach rests on estimates of the value of the product inputs and outputs of each industry. For the years covered, the outputs, deflated by appropriate pricesreceived indexes, less the inputs, deflated by the appropriate prices-paid indexes, would yield estimates of real product in the various industries.

The interindustry chart being prepared for the year 1947 is the first one with a degree of accuracy requisite for good industrial gross product estimates. Possibly data from the charts for previous years could be utilized, at least for broad industrial groupings. However, the fewer the industries included, the less adequate could the deflation procedure be.

For 1947, and later years for which interindustry relationships may be estimated, a basis for real industrial gross product estimates exists which opens the door to adequate industrial productivity estimates for the future by the real product approach.

Meanwhile, certain expedients might be adopted to obtain consistent real product per man-hour estimates by an industrial breakdown. This would involve using productivity estimates on a gross output basis, available for many industries over relatively long time periods in the studies of the National Bureau of Economic Research, the Bureau of Labor Statistics, and others.

If it is assumed that the ratios of the real value of intermediate products consumed to the real value of gross output in the industries concerned have not changed significantly over the period covered, then the available productivity series could be used to move a base period gross product per man-hour in the various industries. The industrial gross product estimates for the base period could be approximated by appropriately adjusting the estimates of national income by industrial origin, or could be estimated from interindustry data.

Either procedure would, however, be an expedient. The assumption of a constant intermediate product ratio is dubious. 


\section{NATIONAL PRODUCTIVITY}

Also, productivity data for large areas of the economy are not available-notably, for trade, service, and finance. Thus, no check could be made by summating industrial real products and comparing them with the over-all estimates.

It would be possible, however, to multiply real product per man-hour for the covered industries (derived by the procedure described above) by the corresponding man-hour data and obtain a total real product for the covered areas. By subtracting this total from total real private nonfarm product, the implied real product of the uncovered industries as a whole would be obtained. By dividing this residual real product by the residual man-hours, an approximation to productivity in the uncovered areas would emerge and could be assessed for reasonableness.

If reasonable, the area not covered could be projected as a whole, in conjunction with the productivity data by industry in the covered area. It is probable that, because of the generally higher rate of growth of productivity in the covered areas than that indicated for the private nonfarm economy as a whole, the average rate of productivity growth in the area not covered, chiefly trade, service, and finance, was below the average rate. Much more work needs to be done in defining the concepts and measuring productivity in these areas before intelligent projections can be made.

\section{Effect on productivity of interindustry shifts}

It was pointed out in Part A that composite real product per man-hour reflects changing proportions of labor input among industries, quite apart from changes in technical efficiency within the component industries. The economic, or weighting, factor in productivity change is usually minor compared with technological factors, but it is significant enough to warrant special treatment in analysis of past trends, and in trend projections.

\section{a. THE FARM-TO-NONFARM SHIFT}

Over the $1909-41$ period covered by our trend analysis, the ratio of man-hours worked on farms to the total worked in the private economy declined from almost 30 percent in the early part of the period to about 20 percent in the latter part. Since real farm product per man-hour averages out at less than one-third of real private nonfarm product during the period, it is clear that the 


\section{NATIONAL PRODUCTIVITY}

relative labor shift would have an upward influence on real private product per man-hour.

The influence of this shift can be measured by comparing real private product per man-hour with variable man-hour weights as computed in Part B-1, on the one hand, with real private product per man-hour computed by weighting real farm product per man-hour and real private nonfarm product per man-hour by constant (1939) man-hour weights, on the other. An index of the influence on productivity in the private economy of the farmto-nonfarm shift is obtained by dividing the variable weighted series by the constant weighted series. This index is plotted in Chart 4.

The general upward trend during periods of relatively full employment is marked. During periods of depression the index moves down, since a reverse shift takes place in depressions, when

\section{CHART 4}

Effect on Productivity in Private Economy of

Form-to-Nonfarm Shift of Mon-Hours, 1909-50

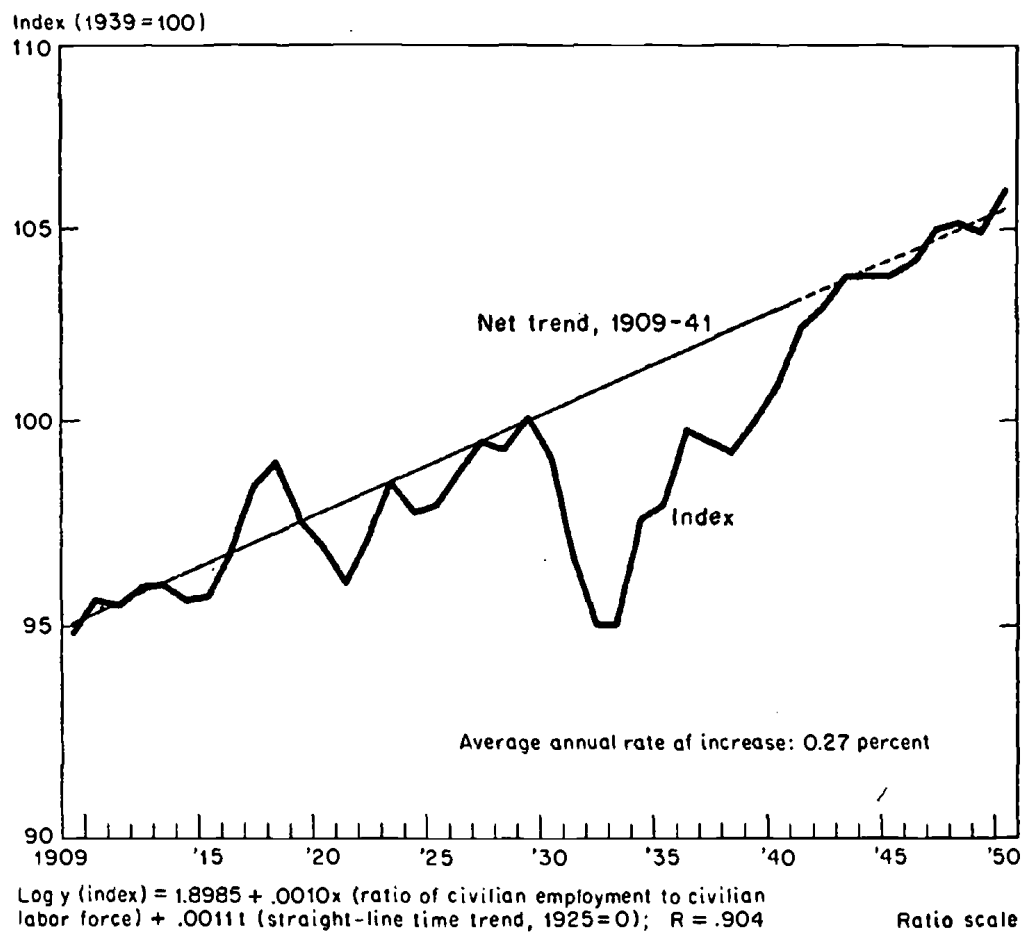


the volume of farm output holds up well relative to nonfarm output as a whole.

The net regression on time, computed from the index of the influence of the farm-to-nonfarm shift on productivity in the private economy, holding the civilian employment ratio constant, yields an average annual rate of increase of 0.27 percent.

Without the influence of the farm-to-nonfarm shifts, productivity in the private economy as a whole (using constant, 1939 manhour weights to combine farm and private nonfarm real products per man-hour) shows an average annual rate of increase of 1.84 percent. This is smaller than the 1.91 rate of growth of productivity in the private nonfarm economy, because growth of productivity in the farm sector is less. But by adding the average rate of increase occasioned by the farm-to-nonfarm shift of 0.27 percent, we obtain a reconciliation with the over-all average annual rate of increase in the private economy as a whole of 2.11 percent.

\section{b. SHIFTS AMONG NONFARM INDUSTRUES}

Since estimates of real product per man-hour for the nonfarm industries are not at hand, it is not possible to compute precisely the effect on private nonfarm productivity of relative shifts of labor among the nonfarm industries.

A crude approximation of the effect of such shifts can be made on the basis of the Department of Commerce employment and national income data for 60 private nonfarm industries for the period 1929-49. This approximation involves the broad assumption that relative levels of national income by industry approximate relative levels of real gross product by industry, and that shifts in the proportions of persons engaged among industries approximate shifts in man-hours worked among industries.

The total number of persons engaged in the private nonfarm industries was distributed for all years by the base period (1939) proportions, and the products of given-year national income per person by industry times persons engaged distributed by industry were summated. By dividing the calculated total into the actual total private nonfarm national income for the various years, an index was obtained which reflects the effects of a shifting distribution of labor input.

This index $(1939=100)$ was 96.1 for 1929 and 100.9 for 1949 . Contrary to what might be expected, excluding the war period, there appears to be an inverse correlation between the index 


\section{NATIONAL PRODUCTIVITY}

and the employment ratio. During the war period, the index reached 104, reflecting the shifts to higher value-added industries.

The average annual rate of increase between 1929 and 1949 is approximately one-quarter of one percent. Inspection indicates that this result is close to what would be obtained by fitting a trend line mathematically to all the observations.

More refined analysis over a longer time period is clearly needed. A highly tentative conclusion is that relative shifts of labor input among private nonfarm industries have been in the direction of increasing the trend of productivity in the private economy. Such shifts in aggregate have apparently been not more important than the farm-to-nonfarm shift alone. If this is true, then interindustry shifts of labor input in the private economy as a whole have accounted for not more than about onefourth of the secular increase in real private gross product per man-hour.

\section{TECHNIQUE OF PRODUCTIVITY PROJECTION}

The chief factors involved in productivity projections have already been implied in the discussion of productivity concepts and measurement. It remains to tie together the factors involved and relate them to the economic projection as a whole.

\section{Over-all projection-first approximation}

Before the forecasters of consumption, investment, and government expenditure patterns go to work, they need a general idea of the total dividend. A first approximation to real gross national product can be obtained by multiplying the projection for the target year of total private man-hours by a projection of real gross private national product per man-hour, and adding a projection of real government product based on a projection of government employment (if government product is treated according to the present Commerce concept).

If the first projection of private real product per man-hour is based on the past growth trend, several major assumptions are implicit:

a. Continuation of past rates of change in the real volume of capital and land per worker, or man-hour, as in the past.

In the case of plant and equipment, the past average rate of replacement and addition would involve rising levels of real 


\section{NATIONAL PRODUCTIVITY}

expenditures for new capital goods, although the future ratios to total gross product could not well be established without actually working out estimates of the total real volume of capital in the past.

The past secular trend of real plant and equipment expenditures represents an average over the business cycle. If the projection for the target year assumes a pathway between now and then under conditions of close to full employment, either the past average rate of new investment would be used, in which case a policy of stimulating other offsets to saving would be implied; or, if a rate of new investment consistent with past periods of high-level employment were assumed, some policy of assuring this high rate would be implied. A program of investment incentives, such as accelerated depreciation allowances, might be the assumption. Under these conditions, in which a higher rate of new investment was assumed than prevailed on the average in the past, an upward adjustment would be called for in the projected rate of growth in productivity.

b. A continuation of the same net effect on over-all private productivity of the shifting distribution of man-hours employed among industries would be assumed.

This assumption becomes increasingly untenable the longer the projection period. It should be checked against the distribution of final demand in the target year by industries. This check, however, would have to be done in a second approximation, since a first approximation to real product is needed before a product and industry break can be made.

c. The same rate of increase in real intangible investment (research and development expenditures) per unit of real factor input as in the past would be assumed.

A fairly steady secular rate of growth in technical productivity seems to be among the more persistent features of a highly industrial economy. In the absence of specific assumptions or forecasts which would alter the tendency to devote increasing amounts of resources to research and development, extrapolation of past rates of aggregate growth seems reasonable.

Insofar as the assumptions for the target year, and the pathway to it, implied special policies accelerating (or retarding) intangible investment, the past rate of pure productivity increase would be modified accordingly. Since the correlation between intangible investment and pure productivity measures has not 


\section{NATIONAL PRODUCTIVITY}

been quantified for past periods, any adjustments in the productivity projection would, of necessity, be subjectively based.

d. Finally, it is clear that projection of past rates of productivity growth assumes no major changes in the socio-economic structure. Social changes might not only alter the conditions covered in the first three points, but could change the general atmosphere within which the economy operates, with particular respect to economic incentives. For example, further substantial alteration in the relative roles of government and the private sectors of the economy could accelerate or retard productivity change via government expenditures, the tax structure, and the general legal framework of the economy..$^{10}$

The remarkable stability of the production function, or the trend in productivity, over a period during which much cumulative change has taken place leads me to believe that only radical social change would be likely to alter past trends substantially. And long-run projections have little meaning unless a relatively high degree of social continuity is assumed.

\section{Productivity projections by industry- successive approximations}

Projection of productivity by as fine an industry break as possible would aid in refining the economic projections for the target year. First of all, they would be of use in arriving at approximations of relative prices, which, in conjunction with total real income and other relevant factors, would be needed to make a final product distribution of total real gross product in the target year.

This breakdown of real product could be translated into a chart of interindustry relationships, which, as we have seen, can be used to obtain real product estimates by industry.

Real product estimates by industry for the target year, in conjunction with industrial productivity projections to the target year, would yield estimates of man-hour requirements. The total man-hour requirements for the target year could then be compared with the projected man-hours-available figure, and any surplus, or deficiency, used to adjust the total real product projection.

If the industry productivity projections were, in aggregate, con-

${ }^{10} \mathrm{Mr}$. Fabricant commented in this connection that the new role of government "may tend to prevent productivity from rising as rapidly in the future as it has in the past." 


\section{NATIONAL PRODUCTIVITY}

sistent with the original over-all productivity projection translated into a constant weighted aggregate, the difference between the final approximation to real product and productivity in the target year, on the one hand, and the first approximation, on the other, would be due to a different set of relative factor input weights than those implied by the first approximation, which assumed a continuation of past trends in relative factor input.

The projection of productivity by industry would also have to take account of the factors spelled out above in connection with the over-all projection. Additional complications would be present in industry productivity projection, however. For one thing, it is likely that the productivity function for many minor industry groups would be more complex than for broader aggregates, with differential rates of productivity change in various phases of industry development.

At this stage of our knowledge, it is unlikely that the aggregate of productivity projections for individual industries would be more accurate than an aggregate projection alone. For this reason the former should probably be tied into the latter on a constantweight basis. The specific adjustments for shifts in weights based on the product distribution in the target year should, however, result in a desirable refinement of the projection of aggregate national productivity. It would be dangerous to assume that the shifts of input factors among industries for a long future period would follow those in the past.

If the spelling out of real product by industry in the target year were accompanied by estimates of capital requirements by industry, a modification of the over-all investment assumption might be required. This would be indicated only insofar as shifts of labor input from industries with lower to those with higher capital per unit of labor input deviated from past patterns.

If product prices in the target year were spelled out in some detail, it would be interesting to revalue the total gross national product in the take-off year by the prices of the target year. This would probably serve to reduce the indicated rate of increase in total real product and productivity, since the products for which demand increases relatively more rapidly are usually those in which productivity increases relatively more rapidly, and relative prices decline. By using target year relative prices as the base for price deflation, less weight would be given to the more rapidly 


\section{NATIONAL PRODUCTIVITY}

expanding outputs, and thus to the related industrial product and productivity measures.

This phenomenon is apparent in measurement of historical aggregate real product and productivity movements in generalthe more recent the price base, the smaller the increase. This does not mean that productivity measurement is an illusion. It merely means that the essence of economics is the relativity of valuesat one point in time and over time. The particular set of values chosen as weights in assessing the real product dividend of productivity measures depends on one's point of view relative to the specific problem.

\section{Areas for further productivity research}

This brief analysis of the projection problem points up the need for much more information regarding productivity.

Although the concept of productivity has been clarified to some extent in this paper, more extensive theoretical thought is needed. This theory would be particularly fruitful if related to the practical problems of productivity measurement. The concept of industrial productivity on a real product basis, in particular, needs to be sharpened, especially in the noncommodity areas, where the definition of output lacks precision.

On an over-all basis, more work needs to be devoted to refining annual estimates of gross national product in constant dollars, especially prior to 1929. Available data on labor force, employment, and average hours worked per week need to be reworked for earlier periods, and the best possible estimates made.

Annual estimates of the total real wealth of the country in terms of productive capital and land will be necessary to obtain productivity measures related to total factor input. Although such estimates are rough at best, they would aid in interpreting past trends, and make possible productivity projections consistent with real investment projections.

Finally, work on productivity by industries needs to be refined and extended. The field of estimates by industry of real product per unit of total factor input is virgin territory. Not only estimates of real product for most industries are needed, but also estimates of man-hours and real property employed in various industries. Even measures of gross output per man-hour have not yet been made for many industries. Annual estimates of total productive capacity, and percentages of capacity utilized, in terms of physi- 


\section{NATIONAL PRODUCTIVITY}

cal units, would also have considerable bearing on the productivity problem, especially in its cyclical aspects.

In many of these areas, it may be impossible to construct adequate historical productivity series. It is never too late, however, to commence gathering and processing data, which, as time passes, will add to our knowledge of this important area of economics. Future generations of economic analysts, forecasters, and policy makers will find their task made more comprehensible by our initiative.

\section{A P P E N D I X}

\section{Sources of the Real Product Estimates Underlying the National Productivity Estimates, 1909-29}

The 1929 Department of Commerce estimates of gross national product, by product groupings, and the corresponding price indexes necessary for deflation were extrapolated back to 1909 by data from the sources listed below.

1. Personal consumption expenditures for commodities: Current-dollar estimates by product groups were extrapolated back by value of output data from William $\mathrm{H}$. Shaw, Value of Commodity Output since 1869 (NBER, 1947). These data, already adjusted for exports and imports, were further adjusted, in the aggregate, for changes in inventories. No adjustment was made for changing distributive markups, so the 1929 average markup is implicitly extrapolated for the entire earlier period.

The price deflators are Shaw's, linked to the implicit Commerce deflators for corresponding minor product groupings as of the year 1929, and thus converted to a 1939 base. Deflation was then carried out by the minor product groupings.

2. Personal consumption expenditures for services: The Commerce current-dollar data by minor groupings were extrapolated back by corresponding groupings from J. Frederick Dewhurst and associates, America's Needs and Resources (Twentieth Century Fund, 1947) for 1909, 1914, 1919, and subsequent odd years through 1929.

Expenditures for housing services (rent) were deflated and interpolated separately. The deflator back to 1914 was the rent component of the Bureau of Labor Statistics consumer price index. Interpolations to the constant-dollar data were made on a straight-line basis. The 1914 constant-dollar rent figure was ex- 
trapolated back to 1909 on the basis of the number of dwelling units in the United States, given in Historical Statistics of the United States, 1789-1945 (Bureau of the Census).

Current-dollar expenditures for other services for the available years were deflated by a weighted average of the "miscellaneous" component of the consumer price index and the "fuel, electricity and ice" component (Bureau of Labor Statistics). Ratios of the constant-dollar other-service expenditures to the constant-dollar nondurable goods expenditures were computed, interpolated on a straight-line basis, and the estimates for the missing years obtained by applying the interpolated ratios to the constant-dollar nondurable goods estimates for those years.

3. New private construction: The 1929 estimate for new private construction (other than oil and gas well drilling) in 1939 dollars was extrapolated back to 1915 on the basis of the 1939-dollar estimates contained in Construction and Construction Materials Report-Statistical Supplement (Construction Division, National Production Authority, Department of Commerce, May 1951). This series was linked in 1915 to series $\mathrm{H}-47$ for residential construction in Historical Statistics of the United States, and lagged permit data for nonresidential construction in Clarence D. Long, Jr., Building Cycles and the Theory of Investment (Princeton University Press, 1940), both deflated by the cost index implicit in series $\mathrm{H}-78$ and $\mathrm{H}-79$ of the former source.

Oil and gas well drilling expenditures, in constant dollars, were extrapolated back of 1929 on the basis of "footage drilled" and "number of wells drilled" data from The Oil Weekly:

4. Producers' durable equipment: The current-dollar data, by product groupings, were extrapolated back by data from Shaw, op.cit., with rough adjustments for inventory change. The value of output of new passenger cars, included by Shaw in consumer durables, was used to extrapolate back the Commerce estimate of passenger cars for business use. The Shaw deflators were linked to the Commerce deflators as of 1929 , and used to deflate the current-dollar estimates by minor groups. Estimated government purchases were explicitly excluded for the World War I years.

5. Change in business inventories: The annual data for the change in nonfarm business inventories, 1919-28, from Simon Kuznets, National Product since 1869 (NBER, 1946), were converted to 1939 dollars. Rough estimates for prior years were based on a relätionship between total nonfarm inventories and gross 


\section{NATIONAL PRODUCTIVITY}

national product excluding services, both in constant dollars, for the period 1918-50. The change in farm inventories was derived from the Bureau of Agricultural Economics estimates for the entire period.

6. Net foreign investment: The current-dollar series, by receipts and payments components, 1919-28, computed by the International Economics Division, Office of Business Economics, Department of Commerce, appears in Historical Statistics of the United States. The commodity part of the balance was carried back to 1909 on the basis of export and import data. The "invisible" items were extrapolated back on the basis of the ratios of the receipts and payments for these items to commodity exports and imports, respectively, for the periods 1896-1914, and 1914-18, based on data from the same source, applied to the commodity exports and imports for the individual years 1909-18. The Department of Commerce unit value indexes for exports and imports for 1913, 1919, and subsequent years were used to deflate receipts and payments separately, with interpolation and extrapolation based on the BLS wholesale price index.

7. Government purchases of goods and services: Federal government expenditures were extrapolated by averages of data for fiscal years, adjusted to exclude interest payments, pensions, and other transfer payments from the Annual Report of the Secretary of the Treasury. Unpublished data of Raymond Goldsmith ${ }^{1}$ were used for the World War I period to improve the phasing. The deduction for compensation of federal general government employees was extrapolated back to 1929 on the basis of data in Simon Kuznets, "National Income, 1919-1938," Occasional Paper 2 (NBER, 1941), and from 1919 back on the basis of numbers of federal general government employees times an extrapolation of the average annual earnings implicit in the Kuznets series. The employment series was based on Civil Service Commission data, and the average earnings series on data presented in Paul $\mathbf{H}$. Douglas, Real Wages in the United States, 1890-1926 (Houghton Mifflin, 1930).

The federal government purchases from the private economy were broken down between "new construction" and "other" by subtracting estimates of the former, based on the Construction Division data cited above, from the total. The 1929 price de-

1 Soon to be available in Dr. Goldsmith's A Study of Saving in the United States (Princeton University Press). 


\section{NATIONAL PRODUCTIVITY}

flator for new federal construction was extrapolated back to 1915 by the implicit deflator for new public construction from the Construction Division data. The "other" purchases deflator was extrapolated back to 1915 by the BLS wholesale price index, and the implicit deflator for all federal purchases in 1915 extrapolated back by the same index.

State and local government purchases were extrapolated back of 1929 by census expenditure data for selected years shown in the Historical Review of State and Local Government Finances (No. 25, Bureau of the Census, June 1948). Provision for debt retirement, aid paid to other governments, interest payments, and contributions to trust funds and enterprises were subtracted from total general expenditures, and interpolations made between the adjusted totals for census years. Compensation of state and local general government employees was extrapolated by methods analogous to those used in the federal segments. Deflation of the purchases from private business was based on the series used for federal purchases. 